\title{
TNF Receptor-Associated Factor 1
}

National Cancer Institute

\section{Source}

National Cancer Institute. TNFReceptor-Associated Factor 1. NCI Thesaurus. Code C105110.

TNF receptor-associated factor 1 ( $416 \mathrm{aa}, \sim 46 \mathrm{kDa}$ ) is encoded by the human TRAF1 gene. This protein plays a role in the regulation of both protein ubiquitination and TNF receptor family-mediated signaling pathways. 